\title{
Обмеження та застереження у фізичній терапії кардіохірургічних пацієнтів після стернотомії
}

\author{
УдК 616.12-039-089.8:615.825
}

\author{
В. В. Вітомський, М. В. Вітомська, С. В. Гаврелюк \\ Національний університет фізичного виховання і спорту України, Київ, Україна
}

\begin{abstract}
Резюме. Хірургічне лікування серцевої патології дуже поширене та ефективне, тому фізична терапія є важливою частиною реабілітаційних заходів для кардіохірургічних пацієнтів. Мета. Дослідити особливості сучасної практики щодо стернальних запобіжних заходів та обмежень у фізичній терапії після кардіохірургічних втручань зі стернотомією. Методи. Аналіз науково-методичної літератури, опитування за допомогою онлайн-сервісу «Google Форми». Результати. Для отриманих результатів встановлено досить велику варіативність за більшістю питань. Це стосувалося обмежень для відведення рук, піднімання вперед та вгору. Діапазон безпечного навантаження при спиранні на ходунок також був великим. Значна частина респондентів визнала забороненим вставання з ліжка через повертання на бік, майже усі визнали забороненим сон у положенні на боці. Показники медіан ваги, яку дозволено піднімати пацієнтам різними способами, відповідали рекомендаціям, що представлені у спеціальній літературі. Майже усі респонденти рекомендували використовувати засоби зовнішньої фіксації груднини, а протоколи усіх місць роботи респондентів передбачали їх застосування усіма пацієнтами. Під час оцінювання функції післяопераційного торакального корсета/бандажа майже усі респонденти відзначили зменшення ризику дегісценції груднини. Порівняння отриманих результатів з рекомендаціями, які вказуються у науковій літературі, встановило як узгодження, так і відмінності, крім того, встановлено відмінності між літературними рекомендаціями. Пошук обґрунтувань традиційних обмежень для пацієнтів після втручань з стернотомією підтвердив, що думки експертів $є$ головним фактором, а також встановив відсутність доказів, що підтверджують конкретні граничні значення обмежень. Ключові слова: мобілізація, активність, амплітуда, навантаження, профілактика, реабілітація.
\end{abstract}

Restrictions and warnings in physical therapy of cardiac surgery patients after sternotomy V. V. Vitomskyi, M. V. Vitomska, S. V. Havreliuk

National University of Physical Education and Sport of Ukraine, Kyiv, Ukraine

Abstract. Surgical treatment of cardiac pathology. It is very common and effective, that is why physical therapy is an important part of rehabilitation measures for cardiac surgery patients. Objective. Investigate the features of modern practice regarding sternal precautions and restrictions in physical therapy after cardiac surgery with sternotomy. Methods. Analysis of scientific and methodological literature, survey using the online service "Google Forms". Results. For the obtained results, a fairly large variability was found for most questions. This referred to restrictions on arm abduction, forward and upward lifting. The range of safe load when leaning on the walker was also large. A significant number of respondents considered getting out of bed by turning to the side to be forbidden like sleeping on the side. The median weight, which patients are allowed to lift in different ways, corresponded to the recommendations presented in the literature. Almost all respondents recommended the use of external sternal fixation devices, and the protocols of all respondents' workplaces provided for their use by all patients. When assessing postoperative thoracic corset / bandage function, almost all respondents reported a reduction in the risk of sternal dehiscence. Comparison of the obtained results with the recommendations indicated in the scientific literature established both agreement and differences; in addition, differences between the literature recommendations were noted. The search for substantiating traditional restrictions for patients after sternotomy interventions confirmed that the opinions of experts are the main factor, as well as indicated no evidence of specific boundary values of restrictions.

Keywords: mobilization, activity, amplitude, load, prevention, rehabilitation. 
Постановка проблеми. Хірургічне лікування серцевої патології дуже поширене та ефективне $[13,36]$. Серединна стернотомія - найбільш часто використовуваний розріз при кардіохірургічних операціях, оскільки забезпечує оптимальний доступ до серця та навколишніх судин $[22,29]$. Вона передбачає поділ груднини центрально і широке розведення країв за допомогою ретракторів [34]. Груднина найчастіше закривається за допомогою дротів з нержавіючої сталі $[29,33]$. У більшості пацієнтів вона заживає добре. Повідомляється про низьку частоту післяопераційних стерильних ускладнень, таких як дегісценція, інфекція та нестабільність (1-5 \%) [34, 37]. Операція на серці вважається серйозною подією для пацієнтів $[4,19]$. У післяопераційному періоді пацієнти можуть відчувати себе залежними від інших [35], а також мати страх завдати шкоди серцю та ділянці хірургічного втручання. Це може призвести до зниження активності [18]. Медичні працівники можуть робити свій внесок у ці припущення пацієнтів, наставляючи їх на дотримання суворих заходів безпеки, щоб уникнути ускладнень з боку груднини [14].

Фізична терапія $\epsilon$ важливою частиною реабілітаційних заходів для кардіохірургічних пацієнтів $[6,49]$. Протоколи запобіжних заходів до пацієнтів, які перенесли серединну стернотомію при кардіохірургічному втручанні, зазвичай розробляють у спеціалізованих установах і використовують під час лікування пацієнтів [5, 14, 31, 47]. Обмеження амплітуди руху та навантаження на груднину часто застосовують для таких пацієнтів, зокрема обмеження односторонніх рухів верхньою кінцівкою та перенесення ваги через верхні кінцівки $[11,14,21,31]$. Незважаючи на поширене використання післяопераційних обмежень, вплив руху та навантаження на верхні кінцівки на загоєння і відновлення груднини залишається невідомим, а профрілактичні заходи базуються лише на теоретичних обґрунтуваннях $[11,14,20$, 47]. Окрім того, профрілактичні заходи піддаються критиці у науковій літературі з тієї причини, що вони є занадто обмежуючими і перешкоджають одужанню пацієнтів та знижують післяопераційну якість життя $[11,14,40,41]$.

Особливості втручань фрізичних терапевтів після серцевої та грудної хірургії раніше досліджували в Австралії та Новій Зеландії [42, 46], у Сполученому Королівстві [43], Канаді [38], Швеції [51] та Греції [32]. Більшість цих робіт вивчали загальні особливості фізичної терапії, хоча деякі 3 них [32, 38, 51] включали питання, пов'язані з профілактичними заходами та обмеженнями 3 причини стернотомії, жодне не стосувалося конкрет- но або детально протоколів та запобіжних заходів, таких як обмеження руху верхньої кінцівки та навантаження. У науковій роботі [47] більш детально показано особливості практики в Австралії щодо стернальних запобіжних заходів. Результати згаданих опитувань фрізичних терапевтів вказують на досить великі відмінності у фрізичній терапії кардіохірургічних пацієнтів між лікарнями та країнами, у тому числі у профрілактичних заходах з причини стернотомії та обмежень.

На території України такі дослідження не проводили. Щоб уточнити їх подальшу перспективу, покращити рекомендації для пацієнтів та створити основу для розробки клінічних вказівок, заснованих на доказах, потрібно задокументувати та оцінити сучасну практику.

Мета дослідження - вивчити особливості сучасної практики щодо стернальних запобіжних заходів та обмежень у фрізичній терапії після кардіохірургічних втручань зі стернотомією.

Методи дослідження: аналіз науково-методичної літератури, опитування за допомогою онлайн-сервісу для створення фрорм зворотного зв'язку «Google Форми».

Результати дослідження та їх обговорення. У дослідженні взяли участь 51 респондент, які працюють у трьох провідних кардіохірургічних лікарнях Києва. До опитування були залучені члени мультидисциплінарної команди, зокрема хірурги, кардіологи, фрізичні терапевти та медичні сестри.

Респондентам повідомляли, що питання будуть стосуватися особливостей активізації дорослих пацієнтів після кардіохірургічних операцій (без захворювань, які впливають на кісткову тканину), обмежень $з$ причини стернотомії та використання торакального бандажа/корсета у післяопераційний період.

Отримані результати було опрацьовано методами математичної статистики. Використовували прикладну програму IBM SPSS Statistics 21. Оскільки результати показників не відповідали закону нормального розподілу, розраховували медіану (Ме) та верхній і нижній квартилі (25\%; $75 \%$ ). Враховуючи особливості дослідження, використовували частотний аналіз та визначення часток пацієнтів відповідно до їх відповідей на запитання.

Серед загальної кількості респондентів частка кардіохірургів становила 25,5 \%, кардіологів - 29,4\%, фрізичних терапевтів - 17,6\%, сестер медичних - 27,5 \%. Показники Ме $(25 \%$; $75 \%$ ) стажу роботи у сорері кардіохірургії становили $7(3 ; 9)$ років. Серед опитаних було чотири 
кандидати наук та один доктор наук, а також один респондент зі званням доцента.

Перший пункт запропонованого опитувальника мав за мету оцінити думки фрахівців про міцність з'єднання груднини після стернотомії за допомогою сталевого дроту. Міцність було визнано достатньою для спокійного дихання 72,5\% респондентів; для глибокого дихання - 68,6 \%; для кашлю - 70,6 \%; для підняття рук вперед $68,6 \%$; для підняття рук у сторони - 54,9\%; для підняття рук вгору - 41,2 \%; для використання обох рук (тяга до себе мотузки) при зміні положення 3 лежачи на сидячи - 76,5 \%; для використання однієї руки (тяга до себе мотузки) при зміні положення 3 лежачи на сидячи $35,3 \%$; для використання однієї руки (відштовхування від ліжка) при зміні положення з лежачи на сидячи - 29,4 \%; для виконання рухів руками при вдяганні одягу без фрурнітури (через голову) $-66,7 \%$.

Досить велика частка респондентів визнала забороненим вставання з ліжка через поворот на бік $(72,5 \%$ ) та спання лежачи на боці $(94,1 \%)$. Щодо вставання 3 ліжка, то 78,4 \% респондентів віддали перевагу моделі 3 використанням мотузки для підняття тулуба за допомогою рук, 9,8 \% - через поворот на бік, а 11,8 \% відзначили відсутність різниці.

Показники Me (25\%; 75 \%) навантаження, яке респонденти вказали як безпечне для спирання обома руками на ходунок під час ходьби, становили 40 (25; 50) \% маси тіла пацієнта, а під час спирання однією рукою на тростину 20 (10; 50) \% маси тіла пацієнта. Мінімальне та максимальне значення в обох випадках становили 0 та $100 \%$ маги тіла пацієнта.

Значення Ме $(25 \% ; 75 \%$ ) у відповідях респондентів про максимальну безпечну вагу, яку пацієнт, з огляду на нещодавню стернотомію, може нести в одній руці на момент виписки, становили $2(1,45 ; 3)$ кг, а мінімальний та максимальний результати - 1 та 7 кг. Щодо аналогічних можливостей пацієнта при перенесенні ваги двома руками (наприклад, загальна маса двох однакових пакетів з магазину), то значення Me (25\%; $75 \%)$ в отриманих відповідях становили 4 (2; 5) кг, а мінімальний та максимальний результати - 1 та 14 кг. Обмеження у можливості піднімати вагу двома руками перед собою становили 2 (2; 4) кг відповідно до отриманих результатів опитування, а мінімальне та максимальне значення - 0 та 10 кг.

Майже усі респонденти (92,2 \%) рекомендували використовувати засоби зовнішньої фріксації (ЗЗФ) груднини у формі торакального бандажа чи корсета у післяопераційний період. У трьох лікарнях використання торакального бандажа/ корсета рекомендували для всіх пацієнтів. Рекомендований термін використання торакального бандажа/корсета становив 3 (2; 3) місяці, а відповідь $з$ максимальним терміном - 6 місяців. У нічний час та під час денного сну 37,3 \% респондентів радили його знімати, 29,4 \% - послабити затягування до вільного, а 33,3 \% - послабити затягування до помірного. Водночас, лише $49 \%$ респондентів вважають, що використання торакального бандажа/корсета $€$ обов'язковим після операції зі стернотомією для усіх пацієнтів. Використання торакального бандажа/корсета після операції зі стернотомією вважають обов'язковим для чоловіків без абдомінального ожиріння 54,9 \% респондентів, для пацієнтів 3 абдомінальним ожирінням - 88,2 \%, для жінок 3 великим розміром молочних залоз - 94,1 \%, для жінок із середнім розміром молочних залоз $68,6 \%$ та для жінок з малим розміром молочних залоз - 47,1 \%. Водночас, лише 19,6 \% респондентів погоджуються 3 тим, що бюстгальтер (у тому числі спортивного типу) може замінити післяопераційний торакальний бандаж/корсет для жінок.

У ході оцінювання частки забезпечення міцності з'єднання груднини від використання торакального бандажа/корсета порівняно з хірургічним з'єднанням сталевим дротом відповіді респондентів мали досить великі варіації: один респондент вважав, що він забезпечує майже всю частину міцності; вісім (15,7 \%) - більшу частину міцності; сім (13,7 \%) - половину міцності; сімнадцять (33,3 \%) - меншу частку; п'ятнадцять $(29,4 \%)$ - невелику частку; три респонденти (5,9\%) - не відіграє ролі.

Щодо строків виникнення необхідності вдягати бандаж/корсет, то шістнадцять респондентів обрали відповідь «у перший післяопераційний день», шістнадцять - «при переведенні пацієнта у положення сидячи», чотирнадцять - «при вертикалізації», найменша кількість респондентів обрала відповіді «при відновленні можливості ходити» та «жоден 3 варіантів (ніколи)» (рис. 1).

Під час оцінювання функції післяопераційного торакального корсета/бандажа майже усі респонденти відзначили зменшення ризику дегісценції груднини, дещо менша частка респондентів $(84,3$ \%) - функцію підвищення відчуття безпеки у пацієнта. Інші варіанти отримали менший відсоток погодження респондентів (рис. 2).

Окрім того, оцінювання необхідності використання торакального бандажа/корсета для запобігання розходженню груднини у латеральному 


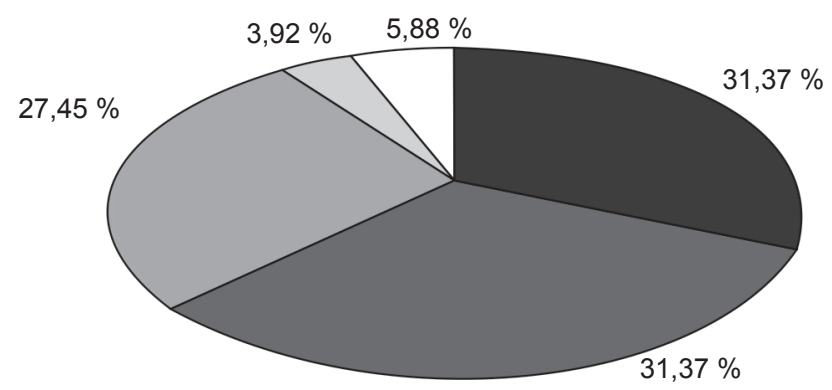

Рисунок 1 - Особливості призначення післяопераційного корсета/бандажа:

- у перший післяопераційний день; переведенні пацієнта у положення сидячи; $\square$ - при - при вертикалізації пацієнта; $\square$ - при відновленні можливості ходити; $\square-$ жоден з варіантів

напрямку виявила, що 9,8 \% респондентів відзначили наявність такої запобіжної дії бандажа/ корсета під час перебування пацієнта у положенні лежачи, 33,3 \% під час сидіння, 72,5 \% - зміни цих положень, 64,7 \% - ходьби, 11,8 \% - спокійного дихання та 74,5 \% під час кашлю. Для запобігання розходженню груднини у передньозадньому напрямку $2 \%$ респондентів відзначили наявність такої запобіжної дії бандажа/корсета під час перебування пацієнта у положенні лежачи, 29,4\% - сидіння, 56,9 \% - зміни цих положень, 39,2 \% - ходьби, 13,7\% - спокійного дихання та 52,9 \% під час кашлю.

Більша частка пацієнтів $(58,8$ \%) погодилися з тим, що торакальний бандаж/корсет може за- побігти зміщенню груднини при падінні пацієнта за умови, що без корсета відбулося б зміщення.

$62,7 \%$ респондентів засвідчили, що бандаж/корсет обмежує дихальні рухи. Проте лише 52,9 \% погодилися 3 тим, що він за правильного використання (туге затягування) може заважати відновленню дихальної системи після кардіохірургічної операції.

На запитання «Наскільки Ви погоджуєтеся 3 твердженням, що усі пацієнти правильно самостійно вдягають корсет і дотримуються рекомендацій щодо його використання?» $62,7 \%$ респондентів обрали відповідь «на половину», 21,6 \% - «в основному так», 15,7 \% - «в основному ні». Варіантів відповідей «безумовно згоден» та «безумовно не згоден» не спостерігалося; «Як Ви вважаєте, яка частка пацієнтів правильно використовує торакальний бандаж/ корсет та дотримується рекомендацій щодо його застосування?» 2 \% респондентів обрали відповідь «усі», 11,8 \% - «майже усі», 45,1 \% - «більша частка», 23,5 \% - «половина», 17,6 \% «менша частка».

Аналіз відповідей респондентів, які віддзеркалювали особливості терміну повного відновлення міцності груднини залежно від віку пацієнта та використання торакального корсета/ бандажа, визначив наявність певної тенденції до збільшення частки респондентів, які обирали більш тривалий термін для старших пацієнтів (табл. 1). Незважаючи на те що більше половини

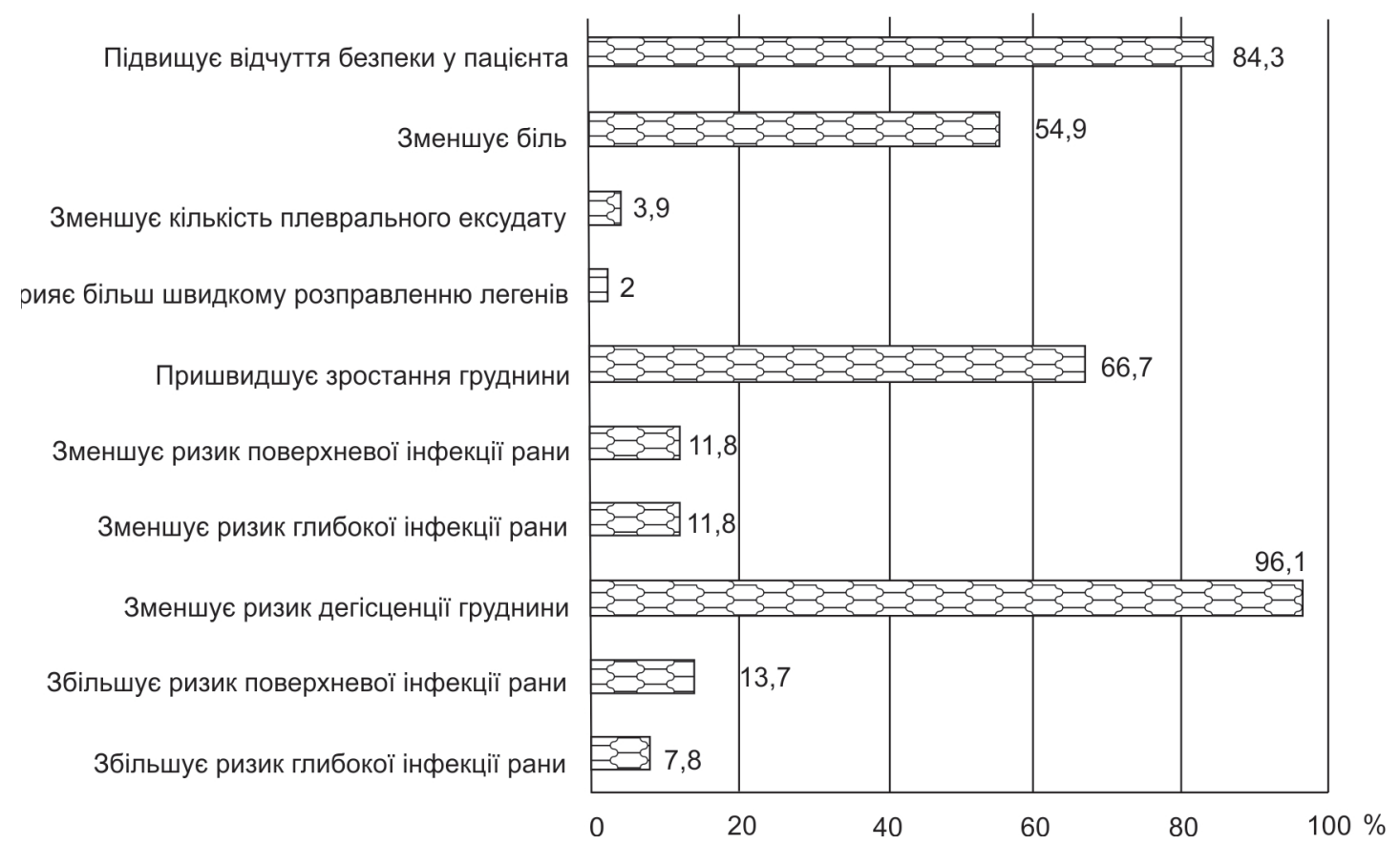

Рисунок 2 - Результати опитування членів мультидисциплінарної команди щодо функцій післяопераційного токарального корсета/бандажа 
ТАБЛИЦЯ 1 - Особливості розподілу відповідей респондентів про термін повного відновлення міцності груднини залежно від віку пацієнта та використання торакального корсета/бандажа

\begin{tabular}{|c|c|c|c|c|c|c|c|c|}
\hline \multirow{2}{*}{ Вік пацієнта } & \multirow{2}{*}{ Умова } & \multicolumn{6}{|c|}{ Термін повного відновлення міцності груднини, місяців } & \multirow{2}{*}{ p } \\
\hline & & 1 & 2 & 3 & 4 & $5-6$ & $>6$ & \\
\hline \multirow{2}{*}{40} & з К. & 15,69 & 25,49 & 54,90 & 1,96 & 0,00 & 1,96 & \multirow{2}{*}{0,091} \\
\hline & без К. & 7,84 & 25,49 & 43,14 & 15,69 & 1,96 & 5,88 & \\
\hline \multirow{2}{*}{50} & $3 \mathrm{~K}$. & 3,92 & 29,41 & 50,98 & 11,76 & 1,96 & 1,96 & \multirow{2}{*}{0,135} \\
\hline & без К. & 3,92 & 13,73 & 50,98 & 11,76 & 13,73 & 5,88 & \\
\hline \multirow{2}{*}{60} & $3 \mathrm{~K}$. & 3,92 & 11,76 & 56,86 & 11,76 & 11,76 & 3,92 & \multirow{2}{*}{0,672} \\
\hline & без К. & 1,96 & 7,84 & 50,98 & 15,69 & 11,76 & 11,76 & \\
\hline \multirow{2}{*}{70} & з K. & 3,92 & 0,00 & 45,10 & 27,45 & 11,76 & 11,76 & \multirow{2}{*}{0,615} \\
\hline & без К. & 1,96 & 1,96 & 31,37 & 33,33 & 17,65 & 13,73 & \\
\hline \multirow[b]{2}{*}{80} & $3 \mathrm{~K}$. & 3,92 & 0,00 & 33,33 & 29,41 & 17,65 & 15,69 & \multirow[b]{2}{*}{0,890} \\
\hline & без К. & 1,96 & 0,00 & 27,45 & 31,37 & 17,65 & 21,57 & \\
\hline
\end{tabular}

Примітка: К. - корсет.

респондентів вказали, що використання корсета/бандажа може пришвидшити зростання груднини (див. рис. 2), статистичних відмінностей при порівнянні особливостей розподілу відповідей респондентів про термін повного відновлення міцності груднини не отримано у жодній віковій категорії (див. табл. 1). Проте не можна заперечити наявність певної тенденції у відповідях, що узгоджується зі згаданими та представленими на рисунку 2 результатами.

Дискусія. Отримані результати характеризуються досить великою варіативністю у відповідях членів мультидисциплінарної команди за більшістю питань. Велику варіативність було встановлено і в інших дослідженнях [47].

Відзначимо, що отримана варіативність відповідей не пояснюється відмінностями між результатами респондентів залежно від місця роботи. Таким чином, причиною виявленої варіативності поглядів на обмеження та застереження у фрізичній терапії пацієнтів після кардіохірургічних втручань зі стернотомією можуть слугувати власний досвід, який може відрізнятися від традиційних та протокольних обмежуючих рекомендацій, та висновки наукових досліджень. Враховуючи, що це дослідження представляє результати опитування членів мультидисциплінарної команди, слід їх порівняти з наявними практичними рекомендаціями та висновками досліджень $з$ подібних тем.

Аналіз наукових електронних баз встановив наявність кількох українських робіт, що включають рекомендації пацієнту після кардіохірургічного втручання зі стернотомією. Зокрема, в одній з робіт [7], яка була виконана науковцем з Інституту серця МОЗ України, вказується на необхідність носіння спеціального корсета (знімається під час відпочинку і сну) для підтримання грудної клітки; дано рекомендації осьових на- вантажень (сидіння, стояння, ходьба) тривалістю більше 10-30 хв, сідати і вставати без перенесення ваги на руки, виконувати піднімання рук не вище рівня плечей. Водночас, ці рекомендації забороняють піднімати і штовхати предмети, важчі 2-4 кг, стояти не більше 5-10 хв за відсутності дискомфорту (запаморочення, слабкість), виконувати сильні і різкі повороти корпусом, лежати на боці, на животі, заводити руки за голову. Щодо термінів цих обмежень, то вони не вказані.

Майже аналогічно до цих рекомендацій у ході проведеного опитування було отримано показники ваги, яку пацієнт може нести в одній та двох руках, на рівні $2(1,45 ; 3)$ кг та $4(2 ; 5)$ кг, а обмеження у можливості піднімати вагу двома руками перед собою на рівні $2(2 ; 4)$ кг. Водночас, отримані результати не відповідали забороні перенесення ваги на руки під час вставання та сідання. Щодо рекомендацій про обмеження піднімання рук вище рівня плечей, то досить велика частка респондентів погодилася 3 тим, що міцність з'єднання груднини після стернотомії достатня для підняття рук вперед $(68,6$ \%), в сторони $(54,9 \%)$ та вгору (41,2 \%). Щодо лежання на боці, то отримані результати загалом відповідали цим рекомендаціям, так, 72,5 \% респондентів визнали забороненим вставання 3 ліжка через поворот на бік та 94,1 \% - сон у положенні лежачи на боці. 3 іншого боку, ці рекомендації не мають посилань на результати досліджень, які обгрунтовують ці застереження та обмеження. Зокрема, не обгрунтовано обмеження у тривалості перебування у положенні сидячи та стоячи, а також певні неузгодження (обмеження стояння тривалістю більше 10-30 хв та стояння більше 5-10 хв).

3 іншого боку, представлені на сайті Інституту серця М03 України рекомендації [8] радять 
підніматися з ліжка через поворот на бік. Про торакальний корсет інформації не знайдено. Інші рекомендації з сайту (не піднімати предметів, важчих 2,5 кг (відро для сміття, сумки з покупками, каструлі, валізи), не відкривати і не закривати розсувні вікна та двері, не рухати меблі, не мити підлогу, не користуватися приладами, які вимагають фрізичного зусилля (наприклад, пилосос), не керувати автомобілем, мотоциклом, велосипедом) загалом узгоджуються 3 попередніми. Окрім того, повідомляється, що середні строки зростання груднини становлять 6 тиж. (саме у цей час потрібно уникати рухів, що створюють навантаження на грудну клітку), а плавання заборонено протягом 3 міс. Перший з цих термінів значно менший, ніж той, що обрала більшість респондентів під час визначення терміну повного відновлення міцності груднини, а другий дуже наближений (див. табл. 1).

В інфрормаційно-освітньому довіднику для дорослих кардіохірургічних пацієнтів [9], який був розроблений у ДУ «Науково-практичний медичний центр дитячої кардіології та кардіохірургії» МОЗ України, вказано, що протягом 6 тиж. після операції заборонено займатися спортом та виконувати розвідні рухи руками. Водночас, упродовж 8-12 тиж. протипоказано підтягуватися, віджиматися та піднімати важкі предмети (більше 3 кг), що, як і попередні рекомендації, дуже наближено до відповідей респондентів про строки відновлення міцності груднини. Про торакальний бандаж та про перенесення ваги на руки при мобілізації не згадується, хоча післяопераційне ведення пацієнта у медичному центрі, де було розроблено довідник, передбачає використання корсета та можливість перенесення ваги на руки за необхідності при мобілізації пацієнта. Окрім того, як і у попередніх роботах, рекомендується уникати важкої роботи вдома (замітання, прибирання пилососом, миття підлоги чи вікон та пересування важких речей). Проте чи можна таку роботу по дому назвати важкою, якщо її може виконати, наприклад, учень молодшої школи, якщо можна змінити її інтенсивність, використати, наприклад, сучасний інвентар для прибирання, а також змінити техніку прибирання пилососом? Лише у цьому довіднику запропоновано жінкам одягати бюстгальтер, щоб запобігти появі болю у ділянці хірургічного доступу. Водночас, лише 19,6 \% опитаних членів мультидисциплінарної команди визнали можливість заміни корсета/бандажа на бюстгальтер.

Зарубіжні рекомендації також мають обмеження $з$ приводу стернальної рани. Зокрема, в одних клінічних рекомендаціях [3] вказано, що у пацієнтів можуть виникати обмеження протягом перших 4-6 тиж., які стосуються їх побутової активності (1 - не водити машину до дозволу кардіохірурга, їздити на задньому сидінні; 2 - обмежити піднімання вантажу руками; 3 - вставати з сидіння, спираючись на ноги, тобто вставати «ногами»; 4 - не брати на руки дітей і тварин, не підвішувати вантаж на ремені, що розташований на талії; 5 - при взуванні тримати ногу на площині вище або «перетинати» надп'ятковогомілковим суглобом рівень протилежного стегна, а не нахилятися вниз до ноги; 6 - не відкривати туго закриті кришки, важкі стулки вікон або дверей; 7 - рекомендується приймати душ, сидячи боком, використовуючи спеціальний стільчик, що дозволяє мінімізувати вплив на грудну клітку; 8 - під час здійснення будь-яких дій виконувати їх двома руками, а також виключати дії, які вимагають відведення рук за спину).

Щодо обгрунтування таких обмежень науковими дослідженнями, то вони не наводяться, а також не надаються кількісні значення деяких обмежень. Зокрема, зовсім незрозумілий механізм дії рекомендації № 7 (невже звичайний душ може пошкодити шкіру у місці рани і тим паче грудну клітку, а стояння - вплинути на цілісність грудної клітки). Можливо, це лише захід обережності щодо можливості падіння та головокружіння, проте про це не вказано. Виконання будь-яких дій двома руками також видається надмірним (рекомендація № 8). Звертає на себе увагу наявність лише обмеження відведення рук за спину (рекомендація № 8), а обмеження піднімання рук вгору було відсутнє, хоча попередні рекомендації обмежували його до рівня плечей. Водночас, у цих рекомендаціях комплекси лікувальної гімнастики для стаціонарного етапу мали вправи з підніманням рук у сторони (додатки 14.3, 14.4 [3]) та вгору, обертання у плечових суглобах, нахили вперед та вбік, повороти, обертання тулубом (додаток 14.4 [3]).

У наступні 8-12 тиж. ці клінічні рекомендації [3] регламентують таке:

1) не піднімати вагу понад 5 кг;

2) бути обережним при зміні положень тіла, уникаючи піднімання ваги; користуватися в цих випадках ногами;

3) не обертати верхню частину тіла, не протирати, не чистити поверхні;

4) уникати підмітання підлоги, плавання, їзди на велосипеді;

5) уникати занять енергійними видами спорту (гольф, теніс, плавання) протягом 3 міс.; перш ніж відновити дані види діяльності, необхідна консультація лікаря. 
ТАБЛИЦЯ 2 - Основні клінічні рекомендації та обмеження для пацієнтів після кардіохірургічних втручань зі стернотомією

\begin{tabular}{|c|c|c|c|c|}
\hline \multirow{2}{*}{ Рекомендації } & \multicolumn{4}{|c|}{ Джерело } \\
\hline & $\begin{array}{c}\text { Опитування } \\
\text { респондентів, \% }\end{array}$ & $\begin{array}{c}\text { Єпанчінцева } \\
\text { [7] }\end{array}$ & $\begin{array}{c}\text { Касьянова } \\
\text { [9] }\end{array}$ & $\begin{array}{c}\text { Бокерія } \\
\text { [3] }\end{array}$ \\
\hline $\begin{array}{l}\text { Піднімання рук: } \\
\text { вперед }\end{array}$ & $\begin{array}{l}\text { 68,6 - міцність } \\
\text { 3'єднання достатня }\end{array}$ & дозволено & не вказано & дозволено \\
\hline в сторони & $\begin{array}{l}\text { 54,9 - міцність } \\
\text { 3'єднання достатня }\end{array}$ & дозволено & заборонено & дозволено \\
\hline вгору & $\begin{array}{l}\text { 41,2 - міцність } \\
\text { 3'єднання достатня }\end{array}$ & заборонено & заборонено & дозволено \\
\hline $\begin{array}{l}\text { Перенесення ваги } \\
\text { на руки (спирання) }\end{array}$ & $\begin{array}{l}\text { медіана - } 40 \text { \% ваги } \\
\text { тіла при спиранні на } \\
\text { ходунок }\end{array}$ & заборонено & не вказано & заборонено \\
\hline $\begin{array}{l}\text { Підіймання } \\
\text { предметів }\end{array}$ & у середньому 2-4 кг & $2-4$ кг & не вказано & до 5 кг з 8-го тижня \\
\hline $\begin{array}{l}\text { Положення на боці } \\
\text { (сон, відпочинок) }\end{array}$ & 94,1 - заборонено & заборонено & не вказано & присутнє позиціювання пацієнта на боці \\
\hline $\begin{array}{l}\text { Перехід у } \\
\text { положення сидячи } \\
\text { через поворот на бік }\end{array}$ & 72,5 - заборонено & не вказано & не вказано & \\
\hline $\begin{array}{l}\text { Використання } \\
\text { торакального } \\
\text { бандажа/корсета } \\
\end{array}$ & $\begin{array}{l}\text { 92,2 - рекомендували; } \\
\text { протоколи лікарень } \\
\text { передбачали }\end{array}$ & необхідно & $\begin{array}{l}\text { не вказано; для жінок } \\
\text { бюстгальтер }\end{array}$ & не вказано \\
\hline $\begin{array}{l}\text { Заборонена } \\
\text { побутова активність }\end{array}$ & - & - & $\begin{array}{l}\text { замітання, прибирання } \\
\text { пилососом, миття підлоги } \\
\text { чи вікон, пересування } \\
\text { важких речей }\end{array}$ & $\begin{array}{l}\text { піднімати на руки дітей і тварин; } \\
\text { відкривати туго закриті кришки, важкі } \\
\text { стулки вікон або дверей, підмітати } \\
\text { підлогу, протирати або чистити поверхні }\end{array}$ \\
\hline
\end{tabular}

У цьому переліку перший, третій, четвертий та п'ятий пункти майже аналогічні рекомендаціям, що були знайдені у ході аналізу української наукової літератури. Щодо другого пункту, то він видається незрозумілим. Третій пункт (обертання тулубом), як уже згадувалося, суперечить змісту комплексів вправ лікувальної гімнастики цих рекомендацій. Окрім того, обертання тулубом легше виконати, ніж активне повертання на бік, який дозволяють ці рекомендації ще з перебування пацієнта у реанімації. Також залишається невідомою причина, що не дала можливості авторам об'єднати рекомендації для 8-12 тиж. з рекомендаціями для перших 4-6 тиж. У цих клінічних рекомендаціях інфрормації про необхідність використовувати торакальний бандаж не знайдено.

Звертають на себе увагу певні формулювання у згаданих рекомендаціях та обмеженнях, зокрема «можуть виникати обмеження», «рекомендується уникати», «не рекомендується», оскільки вони формують відчуття лояльності та необов'язковості.

У деяких наукових статтях також повідомляється про певні обмеження для пацієнтів після кардіохірургічних втручань зі стернотомією. Так, у роботі Л. Н. Анцигіної та П. Н. Кордатова повідомляється, що процес консолідації груднини досить тривалий і може займати кілька місяців. Дослідники вказують, що на ранніх стадіях реабілітації і до відновлення цілісності кістки потрібне дотримання фрізичного спокою груднини. Для iї стабілізації вони рекомендують носити спеціальний бандаж, що фріксує грудну клітку. Протягом усього госпітального періоду вправи для плечового пояса рекомендовано виконувати без зусиль $з$ невеликою амплітудою; виключаються вправи на «розсування» грудної клітки [1].

На противагу цьому положенню, програма фрізичної терапії, що представлена у роботі В. В. Базилєва та Н. В. Гальцевої, передбачала, що пацієнти на 3-4-ту добу після операції відвідують зал лікувальної гімнастики, де обсяг фрізичних занять розширюється до виконання силових навантажень на м'язи верхнього плечового пояса з обтяженням до 2-3 кг [2]. Незважаючи на відмінність цих двох підходів, Л. Н. Анцигіна та П. Н. Кордатов [1], представляючи згадані обмеження у своїй роботі, посилаються на роботу В. В. Базилєва та Н. В. Гальцевої [2] як першоджерело.

Таким чином, клінічні рекомендації, що представлені у спеціальній літературі, мають як спільні риси, так і відмінності (табл. 2), а також досить велику варіативність та суперечності. Отримані результати опитування членів міждисциплінарної ко- 
манди частково узгоджуються з рекомендаціями, що представлені у довідниках. Проте відсутність узгодженості чи явної переваги певних відповідей у ряді питань (зокрема, щодо обмеження амплітуди рухів руками, рівня можливого навантаження), а також обґрунтованості у розглянутих рекомендаціях, посилань на наукові дослідження підкреслює необхідність подальшого аналізу.

Щодо впливу рухів верхніми кінцівками на навантаження на груднину відомо, що під час виконання згинання, відведення і піднімання верхньої кінцівки діє стискаюче механічне навантаження, а значення натягу шкіри на груднині (sternal skin strain - SSS) $€$ негативним. Результати SSS статистично не відрізняються при $90^{\circ}$ та $180^{\circ}$ згинання (близько 10,8 \%), а при $180^{\circ}$ відведення $\epsilon$ статистично меншими, ніж при $90^{\circ}$ відведення. Найбільші результати встановлено для розгинання і відштовхування від стільця, але діапазон SSS мав як позитивні, так і негативні значення. Встановлено відсутність або невелику залежність між рівнем напруження ромбоподібних м'язів і SSS. При збільшенні ваги для підняття над головою домінантною рукою спостерігалася динаміка SSS, але у протилежному напрямку (від $-3,6$ до $-6,8 \%$ ) [23].

За допомогою використання цифррового динамометра встановлено, що виконання шести з 19 завдань активності повсякденного життя для верхньої кінцівки супроводжується піковою швидкістю менше 10 фунтів, а для п'яти завдань перевищує 20 фунтів за умови бажаної швидкості виконання. Під час виконання завдань з низькою швидкістю досягається зменшення пікової сили від 8 до $61 \%$ у всіх, крім одного завдання [44].

При врахуванні цих фрактів представлені обмеження у спеціальній літературі видаються занадто суворими, а відсоток респондентів, які визнали можливим піднімання рук вперед, вгору чи в сторони, малим.

Також важливо, що допомога руками (відштовхування від стола чи ходунка) під час вставання викликає такий самий рівень розширення грудної клітки, як і під час переходу з положення сидячи до стояння без допомоги рук [50]. Активація великого грудного м'яза під час перенесення ваги на руки мінімальна, що дозволяє припустити наявність лише незначного навантаження на груднину [30].

Як показало опитування, одним із традиційних обмежень після стернотомії $€$ заборона спати на боці. Проте оцінювання відношення між зміною положення на боці та стернальними ускладненнями не підтвердила статистичну значущість та суттєву силу такого зв'язку [28]. Водночас по- зиціювання на боці [1, 32], активні повороти на бік $[1,10]$ використовуються у фрізичній терапії.

В одному з досліджень [41] вказано, що орієнтиром для допустимої сили на груднину після стернотомії може слугувати навантаження, що виникає при кашлі, оскільки під час загоєння рани пацієнт багато разів кашляє для очищення легень від мокроти. Дослідження сили, що діє на груднину під час кашлю, виявило, що при нормальному кашлі вона становить 555,3 H (56 кг), а при максимальному - 1666 Н (168 кг) [15]. Схожі дослідження [17, 39, 45] показали, що відповідно до закону Лапласа сила, яка діє на груднину під час дихання, знаходиться у діапазоні від 160 до 400 H, а під час кашлю - від $550 \mathrm{H}$ до 1650 Н. Порівняння навантаження під час кашлю та weightlifting activities встановило перевагу першого, навіть порівняно 3 підніманням 40 фрунтів (близько 18 кг) [41]. Тому міцність з'єднання груднини після кардіохірургічних втручань $€$ значно більшою від рівня рекомендації «не піднімати більше 2-3 кг».

Ультразвукові дослідження вказують на невеликий рух частин груднини після стернотомії та стандартного з'єднання за допомогою стального дроту під час виконання завдань верхніми кінцівками та тулубом серед кардіохірургічних пацієнтів протягом трьох місяців. Водночас, кашель викликає значне збільшення розходження стернальних країв у бічному напрямку порівняно зі станом спокою та іншими завданнями протягом усього періоду спостереження [12].

У науковій літературі наявні дослідження, що підтверджують статистичне зменшення стернальних ускладнень після стернотомії при використанні запобіжних заходів фріксації (ЗЗФ) груднини (корсетів та бандажів) [16, 24], а також перевагу нееластичних торакальних корсетів над бандажами $[25,26]$. Проте ці дослідження здебільшого проводилися одними й тими самими дослідниками. Водночас, якщо порівняти результати досліджень, то можна знайти певні закономірності та неузгодженості, що підкреслюють можливість дії інших фракторів на виникнення ускладнень. Зокрема, аналізуючи результати Celik et al. [16], можна відзначити, що серед групи пацієнтів без хронічних обструктивнних захворювань легень (ХОЗЛ) та без ЗЗФ кількість поверхневої інфекції рани (ПІР), глибоких стерильних ускладнень (ГСУ), дегісценції стернальної рани (ДСР) була дуже невеликою, а також меншою, ніж у роботі Gorlitzer et al. [24] за показниками ПІР та ГСУ в аналогічній групі. Водночас, у роботі Celik et al. [16] відсоток ускладнень серед пацієнтів без ХОЗЛ та ЗЗФ був дуже наближеним та інколи 
навіть меншим, ніж у групах із ЗЗФ інших досліджень [24-26]. Також у дослідженні Celik et al. [16] звертає на себе увагу збільшення кількості ускладнень серед пацієнтів із ХОЗЛ та без ЗЗФ у проспективному дослідженні порівняно з пацієнтами ретроспективного аналізу: ПІР - 3 1,2 до $2,5 \%$ (тобто у два рази), ГСУ - з 4,9 до 6,6\% (на $35 \%$ ), ДСР - з 1,8 до 2,5\% (на $39 \%$ ).

Аналіз робіт Gorlitzer et al. встановив, що в одній з груп без ЗЗФ [24] відсоток ГСУ був меншим, ніж при використанні торакального бандажа $[25,26]$, а також був аналогічним до результату групи торакального корсета в одній із робіт [26]. Схожа ситуація з показниками ПІР: у групі без ЗЗФ [24] відсоток ПІР був наближеним до групи з торакальним бандажем [25, 26], а також дещо меншим від результатів групи торакального бандажа в одній із робіт [26]. Окрім того, отримані статистичні переваги від використання ЗЗФ у згаданих дослідженнях досягалися за рахунок великої кількості пацієнтів, хоча різниця у поширеності ускладнень була невеликою. Не можна відкинути і версію з рекламною метою робіт, а не науковою. Таким чином, питання щодо необхідності використання ЗЗФ залишається невирішеним, а також потребує максимально незалежних досліджень з аналізом клінічно значущого впливу на поширеність ускладнень, а не лише статистичного. Водночас, $є$ роботи [48], які не встановлюють біомеханічних підстав для профрілактичних чи протекторних можливостей ЗЗФ груднини.

У цьому аспекті проведене опитування встановило, що більшість респондентів вважають, що використання ЗЗФ зменшує ризик дегісценції груднини $(96,1 \%)$, а значно менша частка $(11,8 \%)$ вважала, що використання ЗЗФ зменшує ризик поверхневої та глибокої інфекції.

Щодо відновлення міцності груднини після стернотомії, відомо, що лише у $7 \%$ пацієнтів

\section{Література}

1. Анцыгина ЛН, Кордатов ПН. Принципы реабилитации больных ишемической болезнью сердца после хирургической реваскуляризации миокарда [Principles of Rehabilitation of Patients with Ischemic Heart Disease After Surgical Revascularization of Myocardium]. Физическая и реабилитационная медицина, медицинская реабилитация. 2020;2(2):190-9.

2. Базылев ВВ, Гальцева НВ. Физическая реабилитация пациентов в ранние сроки после операции коронарного шунтирования [Physical rehabilitation of patients in the early stages after coronary bypass surgery]. Физиотерапия, бальнеология и реабилитация. 2016;15(3):124-30.

3. Бокерия ЛА, Аронов ДМ, и др. Российские клинические рекомендации. Коронарное шунтирование больных ишемической болезнью сердца: реабилитация и вторичная профилактика [Russian clinical guidelines. Coronary artery bypass grafting in patients with ischemic heart disease: rehabilitation and secondary prevention]. КардиоСоматика. 2016;7(3-4): 5-71.

4. Вітомський ВВ. Аналіз показників терапевтичного альянсу між кардіохірургічними пацієнтами та фізичними терапевтами за результатами анкетування пацієнтів [Analysis of the indicators of the therapeutic спостерігається рентгенологічно підтверджене з'єднання частин груднини через 3 міс. після кардіохірургічних втручань [12]

Підсумовуючи отримані результати та дані спеціальної літератури, слід погодитися з висновком G. L. Irion et al. [27] про те, що думки експертів залишаються головним обгрунтуванням стернальних запобіжних заходів, не існує жодних доказів, які б підтверджували конкретні граничні значення обмежень для пацієнтів [27]. Як і інші дослідження [47], проведений аналіз ставить під сумнів існуючі обмеження через відсутність доказів, невідомий чи недостатньо вивчений їх вплив на результати для пацієнтів та розбіжності у поглядах респондентів, а також рекомендаціях установ.

Висновки. Результати опитування про сучасну практику стернальних запобіжних заходів та обмежень після кардіохірургічних втручань зі стернотомією встановили досить значну варіативність у відповідях членів мультидисциплінарної команди за більшістю питань, що не пояснюється відмінностями, пов'язаними $з$ місцем роботи. Майже усі респонденти рекомендували використовувати засоби зовнішньої фіксації груднини, а протоколи усіх місць роботи респондентів передбачали їх застосування усіма пацієнтами. Порівняння отриманих результатів з рекомендаціями, що вказані у науковій літературі, встановило як узгодження, так і відмінності, крім того, встановлено відмінності між рекомендаціями. Пошук доказів традиційних обмежень підтвердив, що думки експертів залишаються головним обгрунтуванням, та встановив відсутність доказів, які $б$ підтверджували конкретні граничні значення обмежень. Результати опитування членів мультидисциплінарної команди та аналізу літератури вказують на необхідність змін традиційних обмежень.

alliance between cardiac surgery patients and physical therapists based on the results of patient surveys]. Україна. Здоров'я нації. 2020;3/1(61):100-6.

5. Вітомський ВВ. Рання мобілізація кардіохірургічних пацієнтів: перешкоди виконання, протоколи та ефективність [Early mobilization of cardiosurgical patients: performance barriers, protocols and efficiency]. Art of Medicine. 2020;2:131-136.

6. Вітомський ВВ, Аль-Хавамдех ХМ. Роль респіраторної фізичної терапії у відновному лікуванні пацієнтів після кардіохірургічних втручань [ТТе Role of Respiratory Physical Therapy in the Rehabilitation of Patients after Cardiac Surgery]. Український журнал медицини, біології та спорту. 2020;5 (4):17-25.

7. Епанчинцева ОА. Реабилитация больных с ишемической болезнью сердца после операции аортокоронарного шунтирования [Contemporary Aspects of Physical Rehabilitation in Cardiovascular Surgery]. Ліки України. 2014;1:24-5.

8. Институт сердца. Рекомендации для взрослых пациентов [Цитовано 2020 Вер 01]. Доступно: https://www.heart.kiev.ua/ru/rekomendatsii-dlyavzrosly-h-2/ 
9. Касьянова АЮ, Ревенко КА, Бабляк ОД. Ви та ваше серце: [You and your heart.] інформ.-освіт. довід. Київ: ВСВ «Медицина»; 2015. 120 с.

10. Лутай ЮА, Крючкова ОН, Ицкова ЕА, Турна ЭЮ, Жукова НВ, Кучеренко ТВ. Особенности кардиореабилитации пациентов после проведения коронарного шунтирования. Основные положения российских клинических рекомендаций [Features of cardiac rehabilitation of patients after coronary bypass surgery. The main provisions of the Russian clinical recommendations]. Крымский терапевтический журнал. 2018;2:20-5.

11. Adams J, Cline M, Hubbard M, McCullough T, Hartman J. A new paradigm for post-cardiac resistance exercise guidelines. Am J Cardiol. 2006;97:281-6

12. Balachandran S, Denehy L, Lee A, Royse C, Royse A, El-Ansary D. Motion at the sternal edges during upper limb and trunk tasks in-vivo as measured by real-time ultrasound following cardiac surgery: a three-month prospective, observational study. Heart, Lung and Circulation. 2019;28(8):1283-91.

13. Baumgartner WA, Burrows S, del Nido PJ, Gardner TJ, et al. Recommendations of the National Heart, Lung, and Blood Institute Wor-king Group on Future Direction in Cardiac Surgery. Circulation. 2005;111:3007-13.

14. Brocki BC, Thorup CB, Andreasen JJ. Precautions related to midline sternotomy in cardiac surgery: a review of the mechanical stress factors leading to sternal complications. Eur J Cardiovasc Nurs. 2010;9:77-84.

15. Casha AR, Yang L, Cooper GJ. Measurement of chest wall forces on coughing with the use of human cadavers. J Thorac Cardiovasc Surg. 1999:118:1157-8.

16. Celik S, Kirbas A, Gurer O, Yildiz Y, Isik O. Sternal dehiscence in patients with moderate and severe chronic obstructive pulmonary disease undergoing cardiac surgery: the value of supportive thorax vests. J Thorac Cardiovasc Surg. 2011;141:1398-402.

17. Dasika UK, Trumble DR, Magovern JA. Lower sternal reinforcement improves the stability of sternal closure. Ann Thorac Surg. 2003;75:1618-21.

18. Dunckley M, Ellard D, Quinn T, Barlow J. Coronary artery bypass grafting: patients' and health professionals' views of recovery after hospital discharge. Eur J Cardiovasc Nurs. 2008;7:36-42.

19. Dunckley M, Ellard D, Quinn T, Barlow J. Recovery after coronary artery bypass grafting: patients' and health professionals' views of the hospital experience. Eur J Cardiovasc Nurs. 2007;6:200-7.

20. El-Ansary D, Waddington G, Adams R. Control of sternal instability by supportive devices: a comparison of adjustable fastening brace, compression garment, and sports tape. Arch Phys Med Rehabil. 2008;89:1775-81.

21. El-Ansary D, Waddington G, Adams R. Relationship between pain and upper limb movement in patients with chronic sternal instability following cardiac surgery. Physiother Theory Pract. 2007;23:273-80.

22. Gamel AE, Yonan NA, Hassan R, Campbell CS, Deiraniya AK Lawson RA. Treatment of mediastinitis: early modified Robicsek closure and pectoralis major advancement flaps. Ann Thorac Surg. 1998;65:41-6.

23. Ge W, Sfara A, Hians B. Sternal skin strain during shoulder movements and upper extremity activities. Physiotherapy. 2015;101:e449-e450.

24. Gorlitzer M, Folkmann S, Meinhart J, Poslussny P, Thalmann M, Weiss $\mathrm{G}$, et al. A newly designed thorax support vest prevents sternum instability after median sternotomy. Eur J Cardiothorac Surg. 2009;36:335-9.

25. Gorlitzer M, Wagner F, Pfeiffer S, Folkmann S, Meinhart J, Fischlein $\mathrm{T}$, et al. A prospective randomized multicenter trial shows improvement of sternum related complications in cardiac surgery with the Posthorax support vest. Interact CardioVasc Thorac Surg. 2010;10:714-8.

26. Gorlitzer M, Wagner F, Pfeiffer S, Folkmann S, Meinhart J, Fischlein T, et al. Prevention of sternal wound complications after sternotomy: results of a large prospective randomized multicentre trial. Interact CardioVasc Thorac Surg. 2013;17:515-22.

27. Irion GL, Gamble J, Harmon C, Jones E, Vaccarella A. Effects of upper extremity movements on sternal skin stress. Journal of Acute Care Physical Therapy. 2013;4(1):34-40.

28. Kang Y, Bae SJ, Song CE. Relationship between Lateral Position Change and Sternal Complications after Cardiac Surgery through Median Sternotomy. Journal of Korean Critical Care Nursing. 2016;9(1):66-76.

29. Kun $\mathrm{H}$, Xiubin Y. Median sternotomy closure: review and update research. J Med Coll PLA. 2009;24:112-7.
30. LaPier A, Cleary K. Feedback training improves accuracy of estimating upper extremity weight bearing during functional tasks: implications after open heart surgery. Int J Physiother Res. 2019;7(4):3163-72.

31. LaPier TK, Wintz G, Holmes W, Cartmell E, Hartl S, Kostoff N, Rice $D$. Analysis of activities of daily living performance in patients recove-ring from coronary artery bypass surgery. Phys Occup Ther Geriatr. 2008;27:16-35.

32. Lomi C, Westerdahl E. Physical therapy treatment after cardiac surgery: a national survey of practice in Greece. J Clin Exp Cardiolog. 2013;7(004):1-5.

33. McGregor WE, Payne M, Trumble DR, Farkas KM, Magovern JA Improvement of sternal closure stability with reinforced steel wires. Ann Thorac Surg. 2003;76:1631-4

34. Meisler $P$. The sternum support harness for the treatment and prevention of sternotomy pain and the prevention of sternal instability. Cardiopulm Phys Ther J. 2000;11:63-8.

35. Merkouris A, Apostolakis E, Pistolas D, Papagiannaki V, Diakomopoulou E, Patiraki E. Quality of life after coronary artery bypass graft surgery in the elderly. Eur J Cardiovasc Nurs. 2009;8(1):74-81.

36. Miga KC. Trends in cardiac surgery: exploring the past and looking into the future. Crit Care Nurs Clin N Am. 2007;19:343-51.

37. Olbrecht VA, Barreiro CJ, Bonde PN, Williams JA, Baumgartner WA, Gott VL, Conte JV. Clinical outcomes of noninfectious sternal dehiscence after median sternotomy. Ann Thorac Surg. 2006;82:902-8.

38. Overend TJ, Anderson CM, Jackson J, Lucy SD, Prendergast M, Sinclair S. Physical therapy management for adult patients undergoing cardiac surgery: a Canadian practice survey. Physiother Can. 2010;62:215-221.

39. Pai S, Dunn RM, Babbitt R, Lalikos JF, Pins GD, Billiar KL. Characterization of forces on the sternal midline following median sternotomy in a porcine model. J Biomech Eng. 2008;130:051004.

40. Parker RD, Adams J. Activity restrictions and recovery after open chest surgery: understanding the patient's perspective. Proc (Bayl Univ Med Cent). 2008:21:421-5.

41. Parker RD, Adams JL, Ogola G, McBrayer D, et al. Current activity guidelines for CABG patients are too restrictive: comparison of the forces exerted on the median sternotomy during a cough vs lifting activities combined with Valsalva maneuver. Thorac Cardiovasc Surg. 2008;56:190-4.

42. Reeve J, Denehy L, Stiller K. The physiotherapy management of patients undergoing thoracic surgery: a survey of current practice in Australia and New Zealand. Physiother Res Int. 2007;12:59-71.

43. Reeve J, Ewan S. The physiotherapy management of the coronary artery bypass graft patient: a survey of current practice throughout the United Kingdom. Assoc Chart Physiother Resp Care. 2006;27:35-45.

44. Swanson LB, LaPier TK. Upper Extremity Forces Generated During Activities of Daily Living: Implications for Patients Following Sternotomy. Journal of Acute Care Physical Therapy. 2014;5(2):70-6.

45. Trumble DR, McGregor WE, Magovern JA. Validation of a bone analog model for studies of sternal closure. Ann Thorac Surg. 2002;74:739-44.

46. Tucker B, Jenkins S, Davies K, McGann R, et al. The physiotherapy management of patients undergoing coronary artery surgery: a questionnaire survey. Aust J Physiother. 1996;42:129-137.

47. Tuyl LJ, Mackney JH, Johnston CL. Management of sternal precautions following median sternotomy by physical therapists in Australia: a web-based survey. Physical Therapy. 2012;92(1):83-97.

48. Vitomskyi VV. Theoretical model of sternum external fixation functioning in physical therapy of patients following cardiac surgery via sternotomy. Art of Medicine. 2020;3:203-209.

49. Vitomskyi V. The impact of mobilization and other factors on pleural effusion in patients undergoing cardiac surgical procedures. Journal of Physical Education and Sport. 2020; 20(Supplement issue 3):2167-73.

50. Wang C, Goel R, Noun M, Ghanta RK, Najafi B. Wearable Sensorbased Digital Biomarker to Estimate Chest Expansion during Sit-to-Stand Transitions-A Practical Tool to Improve Sternal Precautions in Patients undergoing Median Sternotomy. IEEE Transactions on Neural Systems and Rehabilitation Engineering. 2019;28(1):165-73

51. Westerdahl E, Moller M. Physiotherapysupervised mobilization and exercise following cardiac surgery: a national questionnaire survey in Sweden J Cardiothorac Surg. 2010;5:67. 